\title{
Orofacial therapy in infants with Down syndrome
}

\author{
J.-L. Sixou' ${ }^{1}$, N. Vernusset' ${ }^{2}$ A. Daigneau ${ }^{3}$, D. Watine ${ }^{4}$, L. Marin ${ }^{5}$ \\ 1 University Professor / Hospital Practitioner, Pediatric Odontology, Faculty member of the Dept. \\ of Odontology at the Université de Rennes 1 and Centre Hospitalier Universitaire de Rennes \\ 2 Prothestist, Odontology and Oral Surgery Sectors, Centre Hospitalier Universitaire de Rennes \\ ${ }^{3}$ Speech Therapist, SESSAD [Special Education and Home Care] Down syndrome d'Ille-et-Vilaine \\ (Saint-Grégoire) and Speech Therapist, Rennes \\ ${ }^{4}$ Speech Therapist, Caen \\ ${ }^{5}$ Hospital Practitioner, specific care, Odontology and Oral Surgery Sectors, Centre Hospitalier \\ Universitaire de Rennes
}

\section{ABSTRACT}

Children with Down syndrome (DS) have specific orofacial characteristics including myo-functional disorders. Care of these patients, from the first months of life, needs to involve numerous health professionals. Oral care by dentists can start when the child is three months old with the use of palatal plates that aim at activating and stimulating different functions. This action is complementary of that of speech therapists, physiotherapists, psycho-motor therapists and pediatricians. It helps children with DS learn the various parts of the oral cavity. This is completed by stimulating pinpoint anatomical areas on the face. The goal of this paper is to describe this approach to orofacial pathology and analyze the results of studies published on this topic.

\section{KEYWORDS}

Down syndrome, palatal plate, infant, child

\section{OROFACIAL THERAPY IN INFANTS WITH DOWN SYNDROME}

Down syndrome is the most frequent chromosomal disorder (O90 in the CIM 10 classification). It is a rare disease (number ORPHA: 870). Patients with Down syndrome show several characteristics that have led to talk of characteristics of oro-facial syndrome being associated with Down syndrome. The most important of these are summarized in Table I.
It must also be noted that people affected by Down syndrome have difficulties at the skin and oral levels in localizing stimuli, irrespective of whether they are painful ${ }^{10}$. In other words, the sensory threshold and/ or the sensory threshold tolerance are not the same as those found in the general population, and the response to stimulations often comes later.

Mailing address:

Jean-Louis Sixou - UFR d'odontologie,

2 avenue du Pr Léon-Bernard - 35043 Rennes Cedex

E-mail: jean-louis.sixou@univ-rennes1.fr

Article received: 11-07-2016. Accepted for publication: 18-08-2016.

This is an Open Access article distributed under the terms of the Creative Commons Attribution License (http://creativecommons.org/licenses/by/4.0), which permits unrestricted use, distribution, and reproduction in any medium, provided the original work is properly cited. 
Table I: Characteristics of oro-facial syndrome associated with Down syndrome ladapted from Sixou et al., 2014) $)^{19}$

\begin{tabular}{|c|c|}
\hline & Buccal Characteristics \\
\hline Infectious aspects & $\begin{array}{l}\text { - Development of infectious foci: ENT (ear, nose, throat) and dental } \\
\text { - Aggressive periodontitis and gingivitis, candidiasis }\end{array}$ \\
\hline Functional aspects & $\begin{array}{l}\text { - Persistence of the nausea reflex } \\
\text { - Persistent suction-swallowing strategy } \\
\text { - Distorted micropathways and ingestion of air during meals } \\
\text { - Oral ventilation } \\
\text { - Ineffective personal hygiene } \\
\text { - Delayed or inadequate expression of pain }\end{array}$ \\
\hline $\begin{array}{l}\text { Other related behavioral and } \\
\text { functional aspects }\end{array}$ & $\begin{array}{l}\text { - Low and protrusive position of the tongue } \\
\text { - Lip hypotonia } \\
\text { - Lip gap } \\
\text { - Salivary incontinence } \\
\text { - Bruxism }\end{array}$ \\
\hline Developmental aspects & $\begin{array}{l}\text { - Craniofacial growth disorder } \\
\text { - Underdevelopment of the palate }\end{array}$ \\
\hline Oral abnormalities & $\begin{array}{l}\text { - Disturbed chronology of temporary teeth (often molars first) and delay in exfoliation } \\
\text { - Failure of tooth development (agenesis) is more common } \\
\text { - More frequent microdontia, taurodontism } \\
\text { - Scrotal tongue } \\
\text { - Lingual diastasis } \\
\text { - Class III disturbed articulation }\end{array}$ \\
\hline
\end{tabular}

It is therefore necessary to attempt to intercept functional problems as soon as possible while trying to improve patients' perceptions of their oral cavity and head-neck assembly. This therapy can only be done within the framework of the general care of children, which involves many health professionals $16,17,19$.

\section{WHAT IS THE GENERAL MANAGEMENT FROM BIRTH?}

From birth, children are taken care of by (and at the level of) different organizations: Maisons Départementales des Personnes Handicapées, Centre d'Action Médico-Sociale Précoce, Service d'éducation spéciale et de soins à domicile, etc. The course of treatment differs among children and host sites. Even when management begins early, the oral cavity is not always considered. In this situation, the activation in children at the oral level is usually performed by speech therapists or physiotherapists. Early management, particularly by speech therapists, has significantly changed in the last 20 years. The development of these children has evolved in a positive way, both at the functional and cognitive levels. Taking care of babies with Down syndrome in orthophonics involves offering a caring relationship to families and babies at a very specific time, i.e., the weeks following the birth, typically soon after the announcement 
of the disability. During these weekly meetings, the job of speech therapists is to guide parent-baby interactions by supporting parents in their questions and their trials with their babies and by showing them the skills of their babies during adapted relationship games. The intervention of speech therapy must begin well before the expected time of language development, i.e., before the age of 6 months, as the sensitive period for language development is between 6 months and 3 years. Delays in the acquisition of oral language are always present in children with Down syndrome. Therefore, it is necessary to intervene as quickly as possible for such children to have the bases for language acquisition: visual, auditory, rhythmic, and proprioceptive markers. Beyond cognitive and linguistic aspects, the consequences of the characteristics of oro-facial syndrome with Down syndrome described above justify the early intervention in orthophonic management?
Particular attention should be paid to spoon-feeding and mastication of small pieces (children with Down syndrome have little appetite for new experiments).

Early education, because of multimodal stimulation, allows children and their family to attain the optimal development of language, motor, neuromotor, and social functions. This facilitates successful school integration and social adjustment as future adults whose expectations and quality of life have increased. However, many babies with Down syndrome do not benefit from early therapy due to the lack of knowledge of health care teams, prescribers, and even speech therapists.

The work of functional therapy by dental surgeons should therefore consider the quality of interventions (including whether they are up-to-date) of other health professionals, if any. A partnership among all health care providers is a prerequisite for positive child development.

\section{WHAT ARE THE MANAGEMENT PRINCIPLES OF ODONTOLOGISTS?}

The initial goal is to allow children to become aware of their oral cavity (to improve proprioception), put their tongue in the palate, prevent lip and lingual hypotonia, and allow oral closure (obtaining labial competence). The secondary objective is to acquire or improve oral functions, prevent malformations and underdevelopments related to dysfunction, and make them accustomed to oral care. The action undertaken is based on the work of the Argentine pediatrician Rodolfo Castillo-Morales that included the use of palatal plaques combined with the stimulation of the neuromotor points of the face and neck ${ }^{15}$. This last stimulus is still relevant ${ }^{16,17}$. The plates used vary according to the age of the children and their characteristics. They have a zone of stimulation of the tongue (crater or bead) and an area of activation of the upper lip (strips, beads, or buttons) in common.

Other stimulation elements may be added as appropriate (Figs. 1-3). Plates, studs, grained textures, and beads are made in Orthoresin ${ }^{\circledR}$ (Dentsply Detrey ${ }^{\top \mathrm{M}}$ ) using the sprinkling 


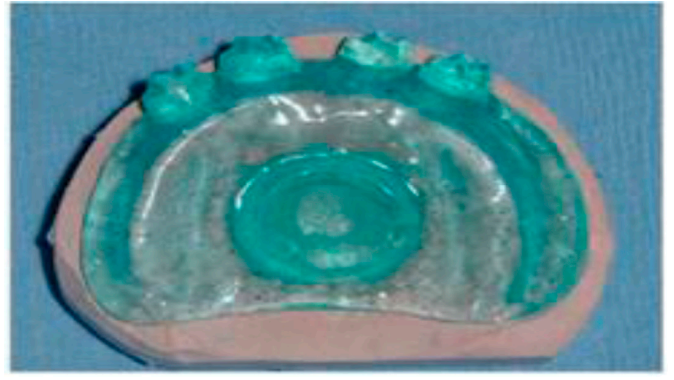

Figure 1

Plate 1: For infants at about 3 months. A maxillary plate with a lip stimulator and tongue activator composed of four resin pads striated at the anterior vestibule and a crater placed behind the palate. The more marked the lingual diastasis is, the more oval is the crater.

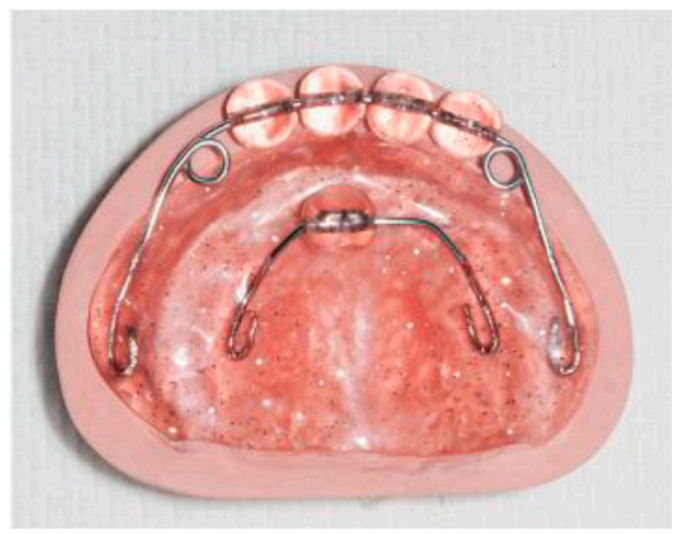

Figure 2

Plate 2: For children between 6 and 9 months. A maxillary plate with a lip stimulator composed of round or ogival beads, according to practitioners' therapeutic instructions. This labial stimulator is placed on a metal arc in the anterior vestibule and equipped with lateral loops, which make it possible to adjust the position of this arc more or less forward. The lingual activator has a faceted palatal bead behind the bunoid papilla placed on a metal wire.

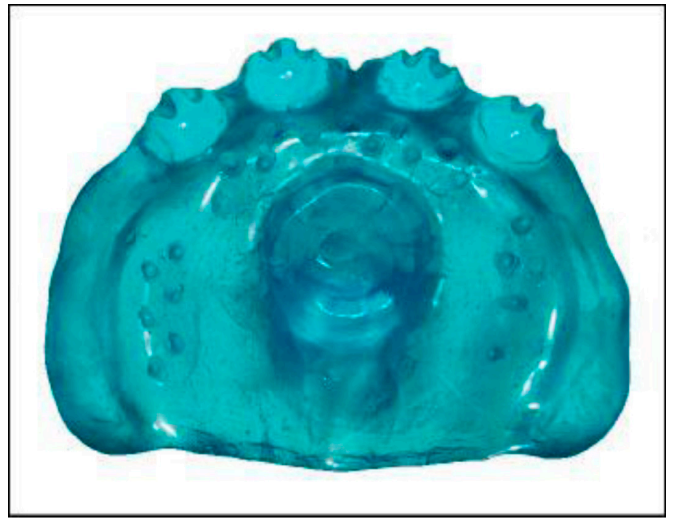

Figure 3

Plate 3: For children between 9 and 13 months. A maxillary plate with a lip stimulator and tongue activators composed of four striated resin pads located in the anterior vestibule, a round crater located in front of the palate with one pip at the center and with a grained palatal surface made with pips on the anterior and posterior sides.

method. They can be transparent or tinted in various colors. Tinting allows prosthetists to have a better vision of the volumes for the parents to find it more easily and finally to associate it with a playful aspect.

Based on the work by Bäckman et al. ${ }^{1}$, three types of plates are consecutively proposed in the Functional Unit of Pediatric Odontology at the Rennes University Hospital (Rare Diseases Center/Odontological Manifestations of Rare Diseases) until the appearance of the first teeth of children. 


\section{WHICH ACTIVATORS TO USE?}

At the level of the palate, a raised, hollow activator, similar to a crater, in the median or posterior position brings the tongue up by placing the back of the tongue against the crater (Fig. 1). It is typically used with the first plate in the youngest children (from 3 months). A bead-type activator is used with the next plate. Located in a more anterior position, it aims to make children play with the tip of the tongue by bringing it to the high retroincisive position (Fig. 2). Complementary activators are used, most often with the third plate, to cause the tongue to explore the lateral areas of the palate. It consists of substantial pips and granulations. They can be located either unilaterally or bilaterally depending on whether one wants to work one side or both. In this third plate, a crater can again serve as activator.

Its position is more anterior than with the first plate to stimulate the tip of the tongue. It makes it possible to prepare to pronounce sibilant consonants ["s" and " $z$ " as fricative sounds "ch" and "j"]. To increase lingual activation, a pip can be added to the center of the crater (Fig. 3). This situation associates the work with the back of the tongue for the sibilant sounds and the one with the tip of the tongue for dental pronunciation.

At the labial level, activation zones must hinder the upper lip, causing children to contract their lip and close the mouth (Figs. 1-3). Even with the mouth closed, these contractions persist and the tongue continues to work. The anterior buttons are effective at the level of the first plate (Fig. 1). Their serrations increase their activation capacity. They should not be too large to allow the upper lip to cover them (maintaining labial movement). An anterior strip bearing beads, resin studs, or any other system may be used (fig. 2). Changing the labial or lingual activator on each plate is also a way to prevent children getting used to it and working less. It is possible on the same plate after a few weeks to make small modifications (new facets on the bead, different overlay) to reinvigorate stimulation. Recent studies have shown that according to the populations of children studied, the indications of form and position may vary according to the age of children or the elements on which one wishes to $\operatorname{act}^{20}$.

\section{HOW OFTEN SHOULD THEY BE USED AND WHEN SHOULD THEY BE CHANGED?}

The goal is that children do not get used to the plates; otherwise, the lips and the tongue no longer work. Parents are asked to have their children wear them 3 times a day for 5 min and to gradually increase the amount of time they are worn for.
There is no rule for maximum duration of wear. The analysis of the literature has shown a great variability of the required wear time, from a few minutes to several hours per day ${ }^{1,3,15}$, preventing a clear recommendation. To adapt to the plate, children may 
stop wearing them when they are no longer working with the plate. When children are examined early enough, the first plate can be placed at the age of 3 months. The change of plate also makes it possible to adapt to the growth of the maxilla. In a conventional time period, the second plate is placed at about 6 months. At this age, the arches are still usually edentulous due to the delayed eruption of the teeth caused by Down syndrome. The third plate is placed at 9 months. These dates are variable for each child.

\section{WHAT IS REBASING?}

Modifications associated with the approach of the temporary teeth and eruption are generally regulated by a simple rebase with the aid of a flexible resin of Viscogel ${ }^{\circledR}$ (Dentsply Detrey ${ }^{\mathrm{TM}}$ ) whose effectiveness is time-limited or of Vertex Soft ${ }^{\circledR}$ (Vertex Dental ${ }^{\mathrm{TM}}$ ) or Mucopren ${ }^{\circledR}$ Soft (Kettenbach $\mathrm{GmbH}$

\section{WHICH RESULTS ARE EVIDENCE-BASED?}

It is difficult to compare published studies. They may be objective, without control groups or random samples, with a decline over the course of 12 years (Tables II and III). Some studies have been performed with control populations of children with Down syndrome who have not received palatal plate therapy (Tables II and III). In general, the results show an improvement in lingual posture and oral closure, as well as a positive effect on language.
When the first teeth are already in place, the third plate is often not used, which is partially confirmed by Bäckman et al., ${ }^{1,2}$ Numerous studies have however shown that the wearing of the plate can be continued during the period of temporary teething or even with temporary teeth (Tables II and III). The question remains whether to continue to seek this type of activation or seek to work in other areas, such as maxillary expansion, when the teeth in place allow adequate retention of the plates.

\& $\mathrm{Co}^{\mathrm{TM}}$ ) that have longer durabilities. When the emergence of the teeth takes place, this simple rebasing is most often more efficient. It may be tempting to combine the use of a flexible resin at the palatal level of the soffit and a harder resin on the edges such as Orthoresin ${ }^{\circledR}$ (Dentsply ${ }^{\mathrm{TM}}$ ).

The best outcome on lingual posture seems to be obtained in children with the most marked signs at the outset ${ }^{11}$. The effect on labial tonicity varies according to publications.

The work by Carlstedt et al. ${ }^{4,5}$ that compared a study group and a control group at 4-year intervals showed a significant improvement in the ability to retract the tongue, keep the mouth closed, in language, and in rounding of the lips when pronouncing words. 
The same study also showed that children who benefited from wearing plates were significantly less susceptible to snoring. However, the differences in the analyzed groups were not significant ${ }^{4,5}$. In general, studies have shown an improvement in motor function and communication skills. Two studies by the same team have shown that at 18 months, there are more teeth on the arch when the plate is worn. The authors attribute this difference to plate stimulation of the oral mucosa leading to an acceleration of tooth eruption ${ }^{1,2}$.

Table II: Principle studies without a control group (with Down syndrome) on the palatal plate in children with Down syndrome. Adapted from Champvalont (2015) ${ }^{6}$

\begin{tabular}{|c|c|c|}
\hline Authors & Population & Results \\
\hline $\begin{array}{l}\text { Glatz-Noll E et al. } \\
(1991)^{8}\end{array}$ & $\begin{array}{l}43 \text { children, age: } 2 \text { months to } 12 \\
\text { years; } 24 \text { children with DS } \\
19 \text { children without DS }\end{array}$ & $\begin{array}{l}\text { Variable results according to children (follow-up at } 4-11 \text { months) } \\
\text { After } 11 \text { months of wearing the plate, } 12 / 24 \text { children had an } \\
\text { improvement in lingual function; no improvement at labial or buccal } \\
\text { closure levels }\end{array}$ \\
\hline $\begin{array}{l}\text { Limbrock G et al. } \\
(1991)^{14}\end{array}$ & $\begin{array}{l}67 \text { children with DS, } \\
\text { Average age: } 13.9 \text { months }\end{array}$ & $\begin{array}{l}\text { Benefit on lingual posture after one year of wearing } \\
\text { Efficacy of muscle hypotonia function plates } \\
\text { Satisfactory results in only } 13.6 \% \text { of children; less effective } \\
\text { for labial hypotonia than for lingual hypotonia } \\
68 \% \text { improvement in salivary incontinence }\end{array}$ \\
\hline $\begin{array}{l}\text { Limbrock G et al. } \\
(1993)^{15}\end{array}$ & $\begin{array}{l}39 \text { children with DS } \\
\text { Average age: } 17.9 \text { months }\end{array}$ & $\begin{array}{l}\text { Study of the immediate effect of plaques on the posture of the tongue } \\
\text { and mouth } \\
\text { Decreased lingual protrusion time when wearing of the plate } \\
\text { Decreased lingual protrusion and better muscular tonicity }\end{array}$ \\
\hline $\begin{array}{l}\text { Hohoff A \& Ehmer U } \\
(1999)^{12}\end{array}$ & $\begin{array}{l}47 \text { children with DS } \\
\text { Average age: } 6.5 \text { months } \\
38 \text { children after } 4 \text { months } \\
18 \text { children after } 53 \text { months }\end{array}$ & $\begin{array}{l}\text { Questionnaire completed by parents } \\
\text { Short- and medium-term improvement in oral and lingual posture } \\
\text { Improvement depending on the degree of initial impairment } \\
\text { The greater the protrusion, the greater the benefit to the tongue }\end{array}$ \\
\hline $\begin{array}{l}\text { Korbmacher H et al. } \\
(2004)^{13}\end{array}$ & $\begin{array}{l}20 \text { children with DS } \\
\text { Average age: } 16 \text { months }\end{array}$ & $\begin{array}{l}12 \text { years after treatment: Improvement in facial appearance } \\
\text { More important effects on the position of the tongue } \\
\text { than on the buccal posture }\end{array}$ \\
\hline Walasz J et al. $(2014)^{20}$ & $\begin{array}{l}50 \text { children with DS } \\
\text { Ages of } 3 \text { months to } 2 \text { years } \\
90 \text { plates placed }\end{array}$ & $\begin{array}{l}\text { Questionnaire with parents and orthodontists and analysis of photos } \\
\text { Improvement in mimicry, lingual retraction, and closing the lips } \\
\text { The palatal crater seems more effective for mimicry } \\
\text { and lip closure } \\
\text { The palatal bead is more effective for lingual retraction } \\
\text { An anterior stimulation position is more effective in the youngest } \\
\text { patients } \\
\text { A central or posterior stimulation position is more effective in older } \\
\text { Patients }\end{array}$ \\
\hline
\end{tabular}


Table III: Principle studies with a control group (with Down syndrome) on the palatal plate in children with Down syndrome. Adapted from Champvalont (2105) ${ }^{6}$

\begin{tabular}{|c|c|c|}
\hline Authors & Population & Results (in groups that wear the palatal plate) \\
\hline $\begin{array}{l}\text { Carlstedt K } \\
\text { et al. }(1996)^{3}\end{array}$ & $\begin{array}{l}24 \text { children with DS distributed in } \\
\text { two groups (control and study) }\end{array}$ & $\begin{array}{l}\text { After a year of myostimulation } \\
\text { Less open mouth, protrusive tongue }\end{array}$ \\
\hline $\begin{array}{l}\text { Hohoff A \& Ehmer U } \\
(1997)^{11}\end{array}$ & $\begin{array}{l}38 \text { children } \\
20 \text { children with DS, average age: } \\
55 \text { months } \\
18 \text { control children, average age: } \\
47.4 \text { months }\end{array}$ & $\begin{array}{l}\text { Improvement in oral motor skills, as well as lingual and oral } \\
\text { position; positive effect on speech development: faster in } \\
\text { children treated with plates }\end{array}$ \\
\hline $\begin{array}{l}\text { Carlstedt K } \\
\text { et al. }(2001)^{4}\end{array}$ & $\begin{array}{l}9 \text { children with DS } \\
\text { Average age: } 5.6 \text { years } \\
\text { (range: } 48 \text { to } 58 \text { months) }\end{array}$ & $\begin{array}{l}\text { After } 4 \text { years of myostimulation } \\
\text { Better labial rounding during pronunciation. Less mouth openness, } \\
\text { protrusive tongue }\end{array}$ \\
\hline $\begin{array}{l}\text { Carlstedt K } \\
\text { et al. }(2003)^{5}\end{array}$ & $\begin{array}{l}20 \text { children with DS } \\
\text { Average age: } 5.5 \text { years ( } \pm 1.5 \\
\text { years) } \\
\text { Study group: } 9 \text { (with a plate) } \\
\text { Control group: } 11 \text { (without a plate) } \\
\text { (sans plaque) }\end{array}$ & $\begin{array}{l}\text { After } 4 \text { years of myostimulation } \\
\text { Less mouth openness, protrusive tongue, snoring } \\
\text { More nasal ventilation, better lip function } \\
\text { Best pronunciation and better-rounded lips during pronunciation }\end{array}$ \\
\hline Bäckman et al. $(2003)^{1}$ & $\begin{array}{l}75 \text { children with DS } \\
<6 \text { months at the start } \\
\text { Study group: } 42 \text { (with a plate) } \\
\text { Control group: } 33 \text { (without a plate) } \\
\text { Control group: } 31 \text { children without } \\
\text { DS }\end{array}$ & $\begin{array}{l}\text { Followed until the age of } 18 \pm 3 \text { months } \\
\text { More teeth on the arch (identical to children without DS) } \\
\text { Best prerequisites for articulation in language } \\
\text { Better oral-motor performance } \\
\text { Plates requiring three steps or badly worn plates in } 19 / 42 \text { children }\end{array}$ \\
\hline Bäckman et al. $(2007)^{2}$ & $\begin{array}{l}67 \text { children with DS } \\
6 \text { months at the start } \\
\text { Study group: } 36 \text { (with a plate) } \\
\text { Control group: } 31 \text { (without a plate) } \\
\text { Control group: } 36 \text { children without } \\
\text { DS }\end{array}$ & $\begin{array}{l}\text { Followed up to the age of } 48 \text { months } \\
\text { More teeth on the arch at } 18 \text { months (identical to children without } \\
\text { DS) } \\
\text { Fewer posterior cross-joints } \\
\text { Increased prevalence of previous end-to-end relationship } \\
\text { Less anterior gap } \\
\text { Better facial expression and better communication ability } \\
\text { (sounds, spoken or signed language) } \\
\text { No effectiveness in decreasing the tendency to class III relationship } \\
\text { of angle }\end{array}$ \\
\hline $\begin{array}{l}\text { Matthews-Brzozowska T } \\
\text { et al. }(2015)^{18}\end{array}$ & $\begin{array}{l}100 \text { children; age: } 2 \text { months } \\
\text { to } 2 \text { years } \\
50 \text { children with a plate } \\
50 \text { control children }\end{array}$ & $\begin{array}{l}\text { Parental questionnaire after } 2 \text { years } \\
\text { Improvement in the muscles of mimicry } \\
\text { Improved lingual retraction and lip closure }\end{array}$ \\
\hline
\end{tabular}

\section{CONCLUSION}

The use of palatal myostimulation plates from the first months seems to give interesting results in the short, medium, and long term. Interest mainly lies in the orofacial motor function and expression, including language. It is important that palatal myostimulation plates are used within the framework of care involving other health professionals.

Conflict of interest: The authors declare that there is no conflict of interest. 


\section{BIBLIOGRAPHY}

1. Bäckman B, Grevér-Sjölander A-C, Holm AK, Johansson I. Children with Down syndrome: oral development and morphology after use of palatal plates between 6 and 18 months of age. Int J Paediatr Dent 2003;13:327-335.

2. Bäckman B, Grevér-Sjölander AC, Bengtsson K, Persson J, Johansson I. Children with Down syndrome: oral development and morphology after use of palatal plates between 6 and 48 months of age. Int J Paediatr Dent 2007;17:19-28.

3. Carlstedt K, Dahllöf G, Nilsson B, Modéer T. Effect of palatal plate therapy in children with Down syndrome. A 1-year study. Acta Odontol Scand 1996; 54:122-125.

4. Carlstedt K, Henningson G, McAllister A, Dahllöf G. Long-term effects of palatal plate therapy on oral motor function in children with Down syndrome evaluated by video registration. Acta Odontol Scand 2001;59:63-68.

5. Carlstedt K, Henningsson G, Dahllöf G. A four-year longitudinal study of palatal plate therapy in children with Down syndrome effects on oral motor function, articulation and communication preferences. Acta Odontol Scand 2003;61:39-46.

6. Champvalont C. L'interception fonctionnelle chez l'en fant porteur de trisomie 21. Thèse Chir Dent. Rennes, 2015.

7. Fantin A, Perie E. Effets de la prise en charge précoce sur la communication prélinguistique dans la triso-mie 21. Mémoire pour le certificat de Capacité d'or-thophoniste. Université Pierre et Marie Curie. Sciences cognitives, dumas-00868934, 2013;79 pages.

8. Glatz-Noll E, Berg R. Oral dysfunction in children with Down's syndrome: an evaluation of treatment effects by means of video registration. Eur J Orthod 1991;13:446-451.

9. Hennequin M, Faulks D, Veyrune JL, Faye M. Le syndrome bucco-facial affectant les personnes porteuses d'une trisomie 21. Info Dent 2000;82:1951-1964.

10. Hennequin M, Morin C, Feine JS. Pain expression and stimulus localisation in individuals with Down's syndrome. Lancet 2000;356:1882-1887.

11. Hohoff A, Ehmer U. Effects of the Castillo-Morales stimulating plate on speech development of children with Down's syndrome. A retrospective study. J Orofac Orthop 1997:58:330-339.

12. Hohoff A, Ehmer U. Short-term and long-term results after early treatment with the Castillo-Morales stimulating plate. J Orofac Othop 1999;60:2-12.

13. Korbmacher H, Limbrock J, Kahl-Nieke B. Orofacial development in children with Down's syndrome 12 years after early intervention with a stimulating plate. J Orofac Orthop 2004;65:60-73.

14. Limbrock GJ, Fischer-Brandies H, Avalle C. Castillo-Morales' orofacial therapy: treatment of 67 children with Down syndrome. Dev Med Child Neurol 1991;33:296-303.

15. Limbrock GJ, Castillo-Morales R, Hoyer H, Stöver B, Onufer CN. The Castillo-Morales approach to orofacial pathology in Down syndrome. Int J Orofacial Myology 1993;19:30-37.

16. Marin L, Riallin M, Palmada E, Sixou JL. Trisomie 21 et thérapie fonctionnelle précoce par plaque palatine. 2013 Le Fil Dentaire 82:10-11.

17. Marin L, Vernusset N, Sixou JL. L'enfant porteur de trisomie 21. 2e partie. Interception fonctionnelle. In : Fiches techniques en odontologie pédiatrique. CdP Éditeuç 2014, p. 313-317. 
18. Matthews-Brzozowska T, Cudziło D, Walasz J, Kawala B. Rehabilitation of the orofacial complex by means of a stimulating plate in children with Down syndrome. Adv Clin Exp Med 2015;24:301-305.

19. Sixou JL, Marin L. L'enfant porteur de trisomie 21. 1 re partie. Prise en charge générale, in Fiches techniques en odontologie pédiatrique. CdP Éditeur 2014;309-312.

20. Walasz J, Matthews-Brzozowska T, Matthews-Kozanecka M, Cudziło D. Types and positioning of palatal plate stimulation elements in children with Down syndrome. J Med Sci Tech 2014;3:1-6. 